\title{
IMPROVING THE STUDENTS' SPEAKING SKILL THROUGH DEBATE TECHNIQUE
}

\author{
Dody Firmansyah $^{\mathbf{1}}$, Else Elvisca Valatansa Vegian ${ }^{2}$ \\ ${ }^{1}$ IKIP Siliwangi \\ ${ }^{2}$ IKIP Siliwangi \\ ${ }^{1}$ dodyfirman191@gmail.com, ${ }^{2}$ elseelviscavalatansavegian@gmail.com
}

\begin{abstract}
Speaking is the highest target in English language because speaking is basis of communication which becomes a function learning. There are many kinds of technique to improve speaking skill and one of them is debate Technique. Therefore, the researcher wanted to find out whether or not debate technique can improve the students' speaking skill and to analyze the classroom situation when debate technique is implemented in speaking class. This research used Collaborative Classroom Action Research and composed for two cycle then it practical and evaluated to categorize all facts including the success and the failure of the action. It means that the action should be stopped or continued and revised to the next cycle based on the selected criteria of success.The application of debate technique in teaching speaking at the first year of SMK Fajar Kencana was accompanied in two cycles including cycle one and cycle two. The members of this study were 29 students in class X AP. This is confirmed by students' test score that upgraded in every cycle. In the cycle 1, the students' got score of pre-test was 64,28. After the implementation of , the students' speaking score were getting better.It can be seen from the result of students'avarage score cycle 1 was 67 and cycle 2 was 78.5. Debate is an appropriate technique used to improve students' speaking skill for the students at SMK Fajar Kencana class X AP. It can be concluded that debate technique can improve students' speaking interest and debate technique can improve speaking classroom into a better situation.
\end{abstract}

Keywords: Speaking Improvement, Speaking Skill, Debate Technique, Classroom Action Research

\section{INTRODUCTION}

Language is a system for the communication of meaning. Its primary function is for interaction and communication (Mcdonough \& Shaw, 2003) in (Arung \& Jumardin, 2016). Language is used by human in order to know and understand each other. As we know that God created human in different condition and character, so they need to interact among people. Communication is one of the implementation of language function in society as a means of carrying out the affairs. One of the ways in communication is through speaking. Speaking is the highest target in English language because speaking is basis of communication which becomes a function learning. Speaking skill is very important in the context of English learning. Richard (2008: 19) in (Parmawati, 2018) states "the mastery of speaking skill in English is a priority for many second language or foreign language learners". There are many kinds of technique to improve speaking skill and one of them is debate Technique. Therefore, the researcher wanted to find out whether or not debate technique can improve the students ${ }^{\text {ce }}$ speaking skill and to analyze the classroom situation when debate technique is implemented in speaking class.

This research has been conducted by several researchers. One of the research had done by (Fernandez Arung, 2016) entitled Improving the Students' Speaking Skill through Debate Technique. In her article, he stated that; (1) debate technique is more effective to teach speaking 
for the tenth grade students of SMA Negri 1 lasusua in the academic year of 2011/2012; (2) the students who have high intelligence have better speaking achievement than the achievement of those who have low intelligence; and (3) there is an interaction between teaching technique and studente s intelligence to teach speaking at the the tenth grade students of SMA Negri 1 lasusua.

According to Brown (2004: 140) in (Fauzan, 2016) "speaking is a productive skill that can be directly and empirically observed, those observations are invariably colored by the accuracy and effectiveness of the test-takers listening skill, which necessarily compromises the reliability and validity of an oral production test". While Thornbury (2005) in (Arung \& Jumardin, 2016) says that speaking is an communicating process and necessitates the ability to cooperate in the organization of speaking turn. Bygate in Torky (2006: 33) in (Arung \& Jumardin, 2016) adopting a definition of speaking based on interactional skills which involve making decision about communication.

From the definitions of speaking skill above, it can be concluded that speaking skill is a productive skill which is part of our daily life and it is difficult to assess reliably. Teaching Speaking. According to Harmer in Nurhaida (2017: 20-21) in (Arung \& Jumardin, 2016), there are many types of classroom speaking activities. They are: a) Acting from script. ; b) Communication games. ; c) Discussion. ; d) Prepares talks. e) Questionnaires ; f) Simulation and Role Play.

Debate is a recognized method of interactive and representative argument aimed at persuading the audience. (Krieger, 2005:1) in (Richa, 2011) states that debate is an excellent activity for language learning because it engages students in a variety of cognitive and linguistic ways. It is provided that meaningful speaking, reading and listening practice, debate is also highly effective for developing argumentation skills for persuasive speech and writing. Alasmari \& Ahmed (2013:148) in (Richa, 2011) claims that debating can be used good to improve up students' speaking in English. The use of debate technique in speaking classes, the learners will first of all drive out students' fear about English language. Moreover, debate technique will improve their pronounciation, vocabulary and fluency.

\section{METHOD}

The design of research which used by the researcher in this Research was Classroom Action Research (CAR). Action research is one of the type analysis that has characteristic participative, collaburative, reflective, and spiral that have resolution to increase and to repair the system, method, process, substance, competence, and situation (Arikunto : 2008) in (Arung \& Jumardin, 2016). Kemmis \& Taggart add in Nunans' book explain that action research is a group of activity and a piece of descriptive research carrie out by the teacher in his or her own classroom, without the contribution of others, which is expected at interesting our understanding rather than changing the singularity.

\section{Planning}

The first phase in doing classroom action research is planning. In this part, the researchers will classified a problematic or subject and change a strategy of act in instruction to take about developments connected with the subject. It includes problem and situation analysis and also prepare the instrument to collect the data. In this action planning the designing lesson plan was decided as well as the material and the media of the teaching process and determining criteria of success. The researchers also develop a teks media in teaching learning process in speaking using debate technique. 


\section{Action}

This phase is the implementation of the plan has been made. Action is implementation of planning which is in this phase means the researcher performed as a teacher and the English teacher performed as an observer in conducting activities based on planning that had been done. In classroom, the researchers conducted writing of descriptive text before teaching the materials, meanwhile the English teacher took note in form of observes all the activities that happen in the teaching learning process. The researchers asked students' to do the writing of the descriptive text using the similar theme. The Students' are not allowed to took at a dictionary. The researchers asked the students' to write any words that come into students' minds.

\section{Observation}

Before conducting the research, the teaching-learning process was not alive as the lecturer used to apply the conventional technique. The students show low participation on speaking class as they were seldom taught to make a better speaking by using various technique because the lecturer monotonous in teaching speaking. The condition after the implementation of the research was showing improvement. The atmosphere of the class more was more live as there are many interesting activities. The student gave attention to the lessons they were very active to conduct the activities and dominated the activities. No more teachers domination

\section{Reflection}

After collecting the statistics, the researcher and the teacher discussed reflection, evaluation and description the outcome of the observation, whether the teaching learning process of writing descriptive text through picture media is good to imply in teaching learning process or not. If the first plan is unsuccessful, the researcher decided to do further cycle of classroom action research to improve the classroom situation and revise the weakness.

Table 1 . Schedule activity

\begin{tabular}{lll}
\hline Meeting & Topic $\quad$ Activities & \\
\hline $\mathbf{1 .}$ & Pretest & Give student pre test speaking. \\
\hline 2. & Treatment I & Viewing slideshow during teaching \\
\hline & (cycle I) & learning activity. \\
\hline 3. & Treatment II & Post speakingactivity. \\
\hline 4. & (cycle I) & \\
\hline $\mathbf{5 .}$ & Post test & Give student test speaking. \\
& Treatment I & Same as cycle I but with video. \\
\hline & (cycle II) & \\
\hline 6. & Treatment II & $\begin{array}{l}\text { Post speaking activity and sharing use the } \\
\text { technique. }\end{array}$ \\
\hline & (cycle II) & \\
\hline
\end{tabular}

\section{RESULTS AND DISCUSSION}

\section{Results}

Debate technique is one of good ways to improve students ${ }^{\text {ee }}$ speaking skill. The improvement of the students ${ }^{\text {ee }}$ ability can also be seen from the results of the students ${ }^{\text {ee }}$ pre-test and post-test which were done in every cycle. The average score of the pre-test was 55.93, the average score 
of the Cycle 1 was 64.28, and the average score of the Cycle 2 was 78.05. All the data showed that the improvement of speaking skill achievement from cycle to cycle was significant. It can be concluded that there was a significant improvement of students ${ }^{\text {ee }}$ speaking skill. The complete data of the last cycle can be seen on the table below.

Table 2 : Post-test average score of cycle II from the first corrector

\begin{tabular}{lll}
\hline No & Explanations & Scores \\
\hline 1. & $\begin{array}{l}\text { The highest } \\
\text { score }\end{array}$ & 87 \\
\hline 2 & $\begin{array}{l}\text { The lowest } \\
\text { score }\end{array}$ & 70 \\
\hline 3 & $\begin{array}{l}\text { The average } \\
\text { score }\end{array}$ & 75
\end{tabular}

Table 3: Post-test average scores of speaking elements of Cycle II first corrector

\begin{tabular}{ccc} 
No & $\begin{array}{c}\text { Speaking } \\
\text { element }\end{array}$ & Average score \\
\hline 1 & Pronunciation & 73,00 \\
\hline 2 & Grammar & 77,00 \\
\hline 3 & Vocabulary & 79,00 \\
\hline 4 & Fluency & 83,00 \\
\hline 5 & Comprehension & 78,00 \\
\hline $\begin{array}{c}\text { Average } \\
\text { score }\end{array}$ & 78,00 \\
\end{tabular}

Table 4: Post-test average score of cycle II from the second corrector

\begin{tabular}{lll}
\hline No & Explanations & Scores \\
\hline 1. & The highest score & 88 \\
\hline 2 & The lowest score & 72 \\
\hline 3 & $\begin{array}{l}\text { The average } \\
\text { score }\end{array}$ &
\end{tabular}

Table 5: Post-test average scores of speaking elements of Cycle II second corrector

\begin{tabular}{lll}
\hline No & $\begin{array}{l}\text { Speaking } \\
\text { element }\end{array}$ & Average score \\
\hline 1 & Pronunciation & 79,00 \\
\hline 2 & Grammar & 82,00 \\
\hline 3 & Vocabulary & 78,00 \\
\hline 4 & Fluency & 79,00 \\
\hline 5 & Comprehension & 78,00 \\
\hline Average score 79,20 &
\end{tabular}

Table 6: Post-test average score of Cycle II from the two correctors

\begin{tabular}{|c|c|c|}
\hline No & Explanation & Scores \\
\hline 1 & $\begin{array}{l}\text { The highest } \\
\text { score }\end{array}$ & 87 \\
\hline 2 & $\begin{array}{l}\text { The lowest } \\
\text { score }\end{array}$ & 71 \\
\hline
\end{tabular}


3 Average score 79,00

\section{CONCLUSION}

The research conclusion is offered allowing with the data which have been examined in the previous chapter. From all the data analysis about using debate technique to improve students' speaking skill at of First Year SMK FAJAR KENCANA, it can be concluded that:

a). The use of debate technique has been supported in teaching speaking process. Characteristically, debate is very concerned to be applied to improve speaking skill. Students have a lot of prospectto practice speaking and have active participation in debate. However, they operated very accommodating and tried to guard their team, and they were more active to speak in classroom.

b). Teaching speaking through debate can be enjoyable experience for both teacher and student. In statistic, students can growth their speaking skill after being taught by debate technique. It can be seen by students' accomplishment in speaking assessment in every cycle. In the first cycle the typical of the students' success was 64,5. In the cycle 2 the average of the students' achievement was 78,4. Students' speaking ability improved as better as their enthusiasm in speaking and they were concerned speaking complete debate. Result of the research show that the students improve their speaking skill efficiently and effectively.

\section{ACKNOWLEDGMENTS}

This project was supported by IKIP Siliwangi Bandung, certainly for English Education Study Programe lecturers'. The researcher are thankful to the Lecture, Mr dasep for guiding us until finished the project, and provided expertise that greatly assisted the research.Although they may disagree with totally of the interpretations provided in this paper.We are also grateful to family and friends for praying and motivate the writer to finish the study at IKIP Siliwangi Bandung. The writer hope this journal could be helpful to reader or other researchers in the future.

\section{REFERENCES}

Arung, F., \& Jumardin. (2016). Improving The Students' Speaking Skill Through Debate Technique. Journal Of English Education, 1(1), 70-76. Https://Doi.Org/Http://Dx.Doi.Org/ 10.31327/Jee.V1i1.85

Fauzan, U. (2016). Enhancing Speaking Ability Of Efl Students Through Debate And Peer Assessment. Efl Journal, 1(1), 49. Https://Doi.Org/10.21462/Eflj.V1i1.8

Nurmalasari, M., \& Apsari, Y. (2014). Improving Students' Participation In Speaking. Ain Shams University Women's College Curricula And Methods Of Teaching Departement, 1(September), 1-254.

Parmawati, A. (2018). Using Analytic Teams Technique To Improve Students'speaking Skill. Edulitics (Education, Literature, And Linguistics) Journal, 3(2), 21-25.

Richa, R. (2011). English Language Teaching Department Faculty Of Tarbiyah Walisongo State Institute For Islamic Studies 2010. Improving Students' Speaking Skill Through Debate Technique. 